\title{
Trichoderma harzianum (Th Azad): A Promising Bio-control Agent Against Lentil Wilt
}

\author{
Anuradha Singh*, Mukesh Srivastava, Mohammad Shahid, Sonika Pandey, Shubha Trivedi, \\ Vipul Kumar and Yatindra Kumar
}

Biocontrol Laboratory, Dept. of Plant Pathology, Chandra Shekhar Azad University of Agriculture \& Technology, Kanpur, Uttar Pradesh (208 002), India

\section{Article History}

Manuscript No. AR1388c

Received in $28^{\text {th }}$ November, 2015

Received in revised form $28^{\text {th }}$ June, 2016

Accepted in final form $18^{\text {th }}$ July, 2016

\section{Correspondence to}

${ }^{*} E$-mail: singhanu1510@gmail.com

\section{Keywords}

Bio-control, Trichoderma harzianum

(Th Azad), seed treatment, stress tolerance

\begin{abstract}
Biological control is an eco-friendly approach for the management of crop diseases. Trichoderma isolate (Th azad), isolated from field soil is a new potential local isolate identified as Trichoderma harzianum. Trichoderma isolate (Th Azad) was tested against lentil wilt pathogen Fusarium oxysporum f. sp. lentis (Fol) for it's abiotic stress tolerance and its antagonistic potential both in vitro and in vivo conditions. Th. Azad effectively inhibited the growth of Fol (69.23\%) under in vitro and field conditions against the seven seed quality attributes viz. germination, shoot length, root length, seedling length, seedling dry weight, vigour index I and vigour index II. Treatment (Th Azad+Vitavax) was found to be significantly superior and effective as it has increased germination of lentil by $8.26 \%$ over control. Trichoderma isolate (Th Azad) was identified by morphological and molecular characterization using 18S rRNA gene sequence with the help of a universal Internal Transcribed Spacer (ITS) marker that gives an amplicon of a total of 1173 base pairs that is later sequenced and allotted with Gene Bank Accession no. JX119211. So, Th Azad is a potential abiotic stress tolerant isolate and can be used for effective management of wilt disease with quality yield of lentil crop when applied as seed dresser at a concentration of $5 \mathrm{~g} \mathrm{~kg}^{-1}$ under field conditions.
\end{abstract}

\section{Introduction}

Pulses play an important role in agriculture. Besides, being rich in protein, it is also a source of atmospheric nitrogen to soil. Lentil is the most important winter pulse crop of India and has potential to cover the risk of dry land agriculture. It is one of the oldest pulse crops with high nutritive value. Besides, it also contains dietary fiber, vitamin $\mathrm{B}_{1}$ and minerals. Lentil is traditionally used as a common item in daily diet of the people. Lentil is affected by biotic and abiotic constraints (Bauske and Kirby, 1992) and various diseases may cause 30$40 \%$ yield loss in lentil. Among the major diseases of lentil, wilt is the most important one. The disease is caused by a soil borne fungus Fusarium oxysporum $\mathrm{f}$. sp. lentis. As there is no effective fungicide or resistant variety for the management of this disease, the farmers can not maintain the optimum plant population in the field and the yield of the crop is drastically reduced.

Seed treatment is an important aspect to obtain higher germination and good quality seedlings (Verma and Kasera, 2008). In view of this, an experiment was carried out to study the abiotic stress tolerance of T. harzianum (Th Azad) and its field bio efficacy in controlling wilt disease in lentil.

Trichoderma is an important bio-control agent against several soil borne phytopathogens. They are free living rapid growing fungi that are common in soil and root eco-system. The fungi are exceptionally good model for bio-control more importantly as bio-agent, which is accomplished by means of mycoparasitism, antibiosis and competition. Diseases caused by soil-borne phytopathogenic fungi pose serious threats to yield of several crops worldwide (Punja, 1988). In biological control of plant diseases use of specific microorganisms that interfere with plant pathogens and pests, is a nature-friendly, ecological approach to overcome the problems caused by standard chemical methods of plant protection (Harman et al., 1994; Harman et al., 2004). Major mechanisms involved in the bio-control activity of Trichoderma spp. are competition for space and nutrients, production of diffusible and/or volatile antibiotics and hydrolytic enzymes like chitinase and $\beta-1$, 3 -glucanase. These hydrolytic enzymes partially degrade the pathogen cell wall and lead to its' parasitization (Kubicek et al., 2001). This process (mycoparasitism) limits growth and activity of plant pathogenic fungi. Different species of 
Trichoderma have the potential to control soil-borne plant pathogens more effectively than chemicals (Papavizas, 1985) and they also exhibit plant-growth promoting activity (Kleifeld and Chet, 1992; Harman and Bjorkman, 1998). They are present in substantial quantity in nearly all agricultural soils and in other environments such as decaying wood and their use is only now being recognized world over as an alternative to plant disease control. Thus, biological control has been exploited as an alternative approach against the chemical control measures in controlling plant pathogens and is currently accepted as a key practice for sustainable agriculture as it is based on the management of natural resources.

\section{Materials and Methods}

Experiments were conducted during rabi 2013-14 crop season, respectively in RBD with three replications. Freshly harvested seeds of lentil (KLB-320) were sown in November during crop season at student research farm of CSA University of Agriculture and Technology, Kanpur, India.

\subsection{Isolation and morphological identification of fungal antagonist}

Soil samples were collected from rhizospheric soil of lentil crop from different places of Uttar Pradesh, India. Trichoderma isolate was isolated and identified on PDA medium by serial dilution plate technique as described by Johnson and Curl (1972). Monoconidial (genetically pure single spore culture) isolate of T. harzianum (Th Azad) was used (Table 1), which was identified by slide mounting and microscopic observation provided by Bissett (1991 a, b) that was later confirmed by Indian Type Culture Collection, IARI, New Delhi.

\subsection{Molecular identification}

Pure culture of the target fungus was grown overnight in liquid Potato Dextrose Broth medium for the isolation of genomic DNA using a method described by Hiney et al. (1992). Total genomic DNA was extracted from isolate of $T$. harzianum (Th-Azad) based on CTAB mini extraction method of Crowhurst et al. (1995) with minor modification. Internal Transcribed Spacer regions of the rDNA gene were used for molecular identification. Two universal primers, ITS-1 (5'-TCCGTAGGTGAACCTGCGG-3') as forward primer and ITS-4 (5'-TCCTCCGCTTATTGATATGC-3') as reverse primer, were used for the molecular identification that gives a uniform banding pattern for Trichoderma harzianum (Th
Azad) isolate. The PCR conditions are followed as described by Shahid et al. (2014).

Sequence analysis of the sequenced gene was initiated with the use of a similarity searching algorithm such as BLAST (Basic Local Alignment Search tool). The database sequences that were found to be $\sim 90 \%$ similar to the test sequence were selected as the best matching homologs and were then subjected to a Multiple Sequence Alignment in the Clustal W program (Thompson et al., 1994). Based on the multiple sequence alignment of the selected sequence set, an evolutionary distance matrix and a phylogenetic tree were then computed using the Neighbor-Joining method. MEGA (Molecular Evolutionary Genetics Analysis) version 4.0 was used for phylogenetic and molecular evolutionary analyses (Tamura et al., 2007). The18S rRNA gene sequence of the test strain was again compared with a different set of sequence databases such as small subunit ribosomal RNA (SSU rRNA) and large subunit ribosomal RNA (LSU rRNA) using Ribosomal RNA BLAST program (Cole et al., 2009). The annotated information for the sequence in the database to which $18 \mathrm{~S}$ rRNA aligns is used for the fungal identification.

\subsection{Isolation of fungal pathogen}

The plant pathogenic fungus $F$. oxysporum f. sp. lentis was originally isolated from the roots of naturally infected lentil plants from a diseased experimental plot at the student research farm of CSAUA\&T, Kanpur, India. For this, the infected roots were first surface sterilized with $0.5 \%(\mathrm{v} / \mathrm{v})$ sodium hypochlorite for $5 \mathrm{~min}$ and subsequently washed three times with sterilized deionized water (Tanwar et al., 2013). The root pieces were then plated on Potato Dextrose Agar (PDA) (Hi-Media Laboratories Pvt. Ltd., Mumbai, India) medium at $25 \pm 2{ }^{\circ} \mathrm{C}$ for 2 weeks. Sub culturing was done with the peripheral mycelium to get the pure culture. Identification of Fusarium was done using the manual (Booth (1971); Leslie and Summerell, 2006). It is further multiplied on PDA broth with $1 \%$ agar for 1 week at $25 \pm 2{ }^{\circ} \mathrm{C}$ to obtain a concentration of $1 \times 10^{5}$ colony forming units (cfu) $\mathrm{ml}^{-1}$

\subsection{In vitro screening of abiotic stress tolerance}

\subsubsection{High temperature tolerance}

In vitro high temperature tolerance of Th Azad was determined by a method described by Daniel et al., 2011. A $5 \mathrm{~mm}$ disc of T. harzianum was inoculated on the potato dextrose agar

\begin{tabular}{lcccccc}
\hline \multicolumn{2}{l}{ Table 1: Identification of potential strains of T. harzianum (Th Azad) } \\
\hline $\begin{array}{l}\text { Isolate } \\
\text { no. }\end{array}$ & Name of bioagent & ITCC acc. no & $\begin{array}{c}\text { Gen bank } \\
\text { accession no. }\end{array}$ & Strain code & Source & GPS location \\
\hline $\mathrm{T}_{1}$ & T. harzianum & 6796 & KC800922 & Th Azad & $\begin{array}{c}\text { CSA Kanpur } \\
\text { Nagar }\end{array}$ & $\begin{array}{r}\text { Latitude: } 25^{\circ} 8^{\prime} 34.821^{\prime \prime} \\
\text { Longitude: } 81^{\circ} 59^{\prime} 2.979^{\prime \prime}\end{array}$ \\
\hline
\end{tabular}


(PDA) at pH 6.5 and incubated at $30^{\circ} \mathrm{C}, 35^{\circ} \mathrm{C} 40^{\circ} \mathrm{C}, 45^{\circ} \mathrm{C}$ and $50{ }^{\circ} \mathrm{C}$ temperature. To check the impact of temperature during growth and sporulation. Future climates will also be affected by greater variability in temperature and increased frequency of hot days. To adapt new bio-agent to the future climate, we need to understand how Th Azad (T. harzianum) respond to elevated temperatures and how tolerance to heat can be improved (Halford, 2009). The results were recorded based on growth and sporulation pattern compared to control plates which were incubated at $30^{\circ} \mathrm{C}$ temperature.

\subsubsection{Salinity tolerance}

In vitro screening of salinity tolerance, a $5 \mathrm{~mm}$ disc of $T$. harzianum (Th Azad) was placed on 0.1, 0.50, 1.00, 1.50, and $2.0 \mathrm{M} \mathrm{NaCl}$ amended in PDA medium and incubated at $30^{\circ} \mathrm{C}$ for 5 days. Percentage reduction of growth in salt amended media was calculated by using the formula $(100 \times A-B / A)$, where A is radial growth in control plate in ' $\mathrm{mm}$ ' of the isolate and $\mathrm{B}$ is radial growth in salt amended plate.

\subsubsection{In vitro confrontation assays}

In vitro mycoparasitism of T. harzianum (Th Azad) against test phytopathogen Fusarium oxysporum f. sp. lentis was determined by dual culture technique described by Morton and Stroube (1955). A disc of $5 \mathrm{~mm}$ diameter was made from 7 days old culture of $T$. harzianum placed at one point leaving $1 \mathrm{~cm}$ distance from the periphery of one side of PDA Petri plate and on the opposite site, a disc (5 mm dia.) of Fusarium oxysporum f. sp. lentil placed separately. Plate was kept without antagonist and it was served as control. These Petri plates were incubated at $30{ }^{\circ} \mathrm{C}$ for 7 days. Three replications were kept for each treatment (Table 3). Observations on colony growth were recorded and percent inhibition was measured by using the formula as described above.

\subsubsection{In vitro seed treatment}

Freshly harvested seeds of lentil (KLB-320) were procured from the seed processing plant of CSA University of Agriculture \& Technology, Kanpur. One hundred seeds were counted and weighed to apply the recommended dose of insecticide, pesticide, formulation of bio-control agent and bio-fertilizer into 3 replications. The test included four treatment base materials viz., one bio-control agent (T.harzianum@4 $\mathrm{g} \mathrm{kg}^{-1}-\mathrm{T}_{1}$ ), one fungicide (Vitavax @ $2 \mathrm{~g} \mathrm{~kg}^{-1}$ seed- $\mathrm{T}_{2}$ ), one insecticide (Chloropyriphos $20 \mathrm{EC}$ (a) $8 \mathrm{ml} \mathrm{kg}^{-1}$ seed $\left.-\mathrm{T}_{3}\right)$, and one bio-fertilizer Rhizobium culture $\left(30 \mathrm{~g} \mathrm{~kg}^{-1}\right.$ seed $\left.-\mathrm{T}_{4}\right)$. Eleven treatments of different combination of base materials (T. harzianum +Vitavax $\left.-\mathrm{T}_{5}\right),(T$. harzianum + Chloropyriphos $\left.-\mathrm{T}_{6}\right)$, (T. harzianum + Rhizobium culture- $\left.\mathrm{T}_{7}\right),\left(\right.$ Vitavax + Chloropyriphos- $\mathrm{T}_{8},($ Vitavax + Rhizobium culture- $\left.\mathrm{T}_{9}\right),\left(\right.$ Chloropyriphos + Rhizobium culture- $\left.\mathrm{T}_{10}\right),(T$. harzianum + Vitavax + Chlorpyriphos $\left.-\mathrm{T}_{11}\right)$, $(T$. harzianum
+ Vitavax + Rhizobium culture- $\left.\mathrm{T}_{12}\right)$, (T. harzianum + Chlor opyriphos + Rhizobium culture- $\mathrm{T}_{13}$ ), (Vitavax + Chloropyr iphos + Rhizobium culture- $\left.\mathrm{T}_{14}\right)$, (T. harzianum +Vitavax + hloropyriphos + Rhizobium culture- $\mathrm{T}_{15}$ ) and one without any seed treatment served as control $\left(\mathrm{T}_{16}\right)$. All the treatments were tested as dry seed treatment method (Nene and Thaaliyal, 1977), with the help of paper towel method (Shailbala and Tripathi, 2004; Singh et al., 2013). The treated seeds were subjected to assess the germination and vigour as per the procedure recommended by ISTA at laboratory of Dept. of Seeds Science \& Technology, CSAUA\&T, Kanpur, India.

Two recommended methods viz., germination $\% \times$ seedling length for vigour index I (Abdul Baki and Anderson, 1973) and germination $\times$ dry weight for vigour index-II was adopted during the course of investigation. According to ISTA these parameters are required for the conformation of our study.

\subsection{Field experimental design and seed treatment}

A field trial was conducted in a randomized block design $(5 \times 5$ $\mathrm{m}^{2}$ ) with one lentil cultivar (KLB-320) at student research farm of CSAUA\&T, Kanpur, India. The sick plot was inoculated with inoculum of Fusarium oxysporum f. sp. lentis. For field experiment, seeds were treated and sown in plots $5 \times 15 \mathrm{~cm}^{2}$ spacing. Germination was recorded 10 days after sowing (DAS). The wilt incidence was recorded after one month of sowing at 15 days interval till harvest. After maturity, dry weight of the plants and grain yield $\mathrm{kg} \mathrm{ha}^{-1}$ were recorded.

\section{Results and Discussion}

\subsection{Morphological description}

Morphology of Trichoderma harzianum (Th Azad) is a key identification characteristic such as colony morphology, colony colour, growth pattern and speed along with morphology of conidia and phialids, conidia colour, shape and size of conidia and phialids etc., as reported in Table 2 and Figure 1.

\subsection{Molecular description}

Rapid identification of microorganisms is necessary in the pathological laboratory to take decision for preparation of bio-formulation. The rRNA based analysis is a central method in pathology used not only to explore microbial diversity but also to identify new strains. The genomic DNA was extracted from isolated fungal isolate Trichoderma harzianum (Th Azad) and universal ITS-1 Forward primers 5'AGAGTTTGATCCTGGCTCAG3' and ITS-4 Reverse primers 5'GGTTACCTTGTTACGACTT3' was used for the amplification and sequencing of the 18S rRNA gene fragment (Singh et al., 2014). A total of $546 \mathrm{bp}$ (Figure 2) of the $18 \mathrm{~S}$ rRNA gene was sequenced and used for the identification of isolated fungal strain. Comparison of test isolates against known sequences of SSU rRNA and LSU rRNA databases 


\begin{tabular}{|c|c|c|c|c|c|c|c|c|c|c|c|}
\hline $\begin{array}{l}\text { Name } \\
\text { of iso- } \\
\text { late }\end{array}$ & $\begin{array}{l}\text { Colony } \\
\text { growth rate } \\
\left.(\mathrm{cm} \mathrm{day})^{-1}\right)\end{array}$ & $\begin{array}{l}\text { Colony } \\
\text { colour }\end{array}$ & $\begin{array}{l}\text { Reverse } \\
\text { colour }\end{array}$ & $\begin{array}{l}\text { Colony } \\
\text { edge }\end{array}$ & $\begin{array}{l}\text { Mycelial } \\
\text { form }\end{array}$ & $\begin{array}{l}\text { Mycelial } \\
\text { colour }\end{array}$ & $\begin{array}{l}\text { Conid- } \\
\text { iation }\end{array}$ & $\begin{array}{l}\text { Conid- } \\
\text { iophore } \\
\text { branching }\end{array}$ & $\begin{array}{l}\text { Conidial } \\
\text { wall }\end{array}$ & $\begin{array}{l}\text { Co- } \\
\text { nidial } \\
\text { colour }\end{array}$ & $\begin{array}{l}\text { Chlaymy- } \\
\text { dospore }\end{array}$ \\
\hline $\begin{array}{l}\text { T. har- } \\
\text { zianum }\end{array}$ & $\begin{array}{c}8-9 \text { in } 3 \\
\text { days }\end{array}$ & $\begin{array}{l}\text { Dark } \\
\text { green }\end{array}$ & $\begin{array}{c}\text { Colour } \\
\text { less }\end{array}$ & Wavy & $\begin{array}{l}\text { Flocose to } \\
\text { Arachnoid }\end{array}$ & $\begin{array}{l}\text { Watery } \\
\text { white }\end{array}$ & $\begin{array}{c}\text { Ring } \\
\text { like } \\
\text { zones }\end{array}$ & $\begin{array}{l}\text { Highly } \\
\text { branched, } \\
\text { regular }\end{array}$ & Smooth & $\begin{array}{l}\text { Dark } \\
\text { green }\end{array}$ & $\begin{array}{c}\text { not } \\
\text { observed }\end{array}$ \\
\hline
\end{tabular}
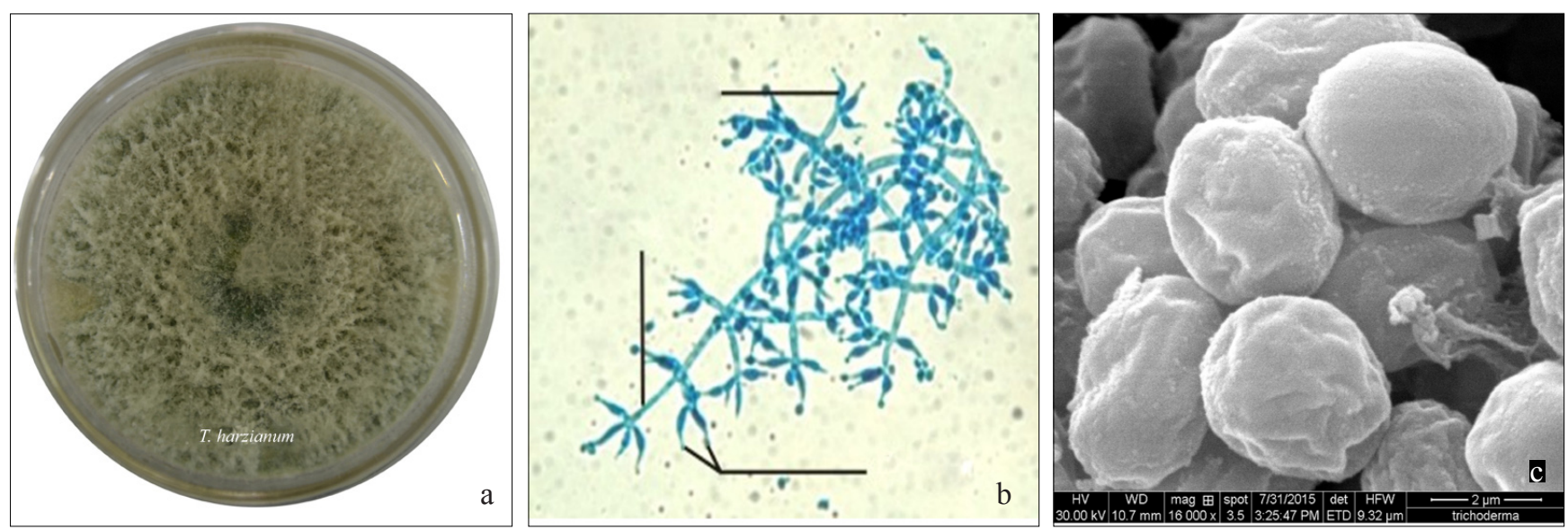

Figure 1: T. harzianum (Th Azad); a: Growth on PDA medium; b: Microscopic observation on 40X; c: Scanning electron micrographs of T. harzianum spores

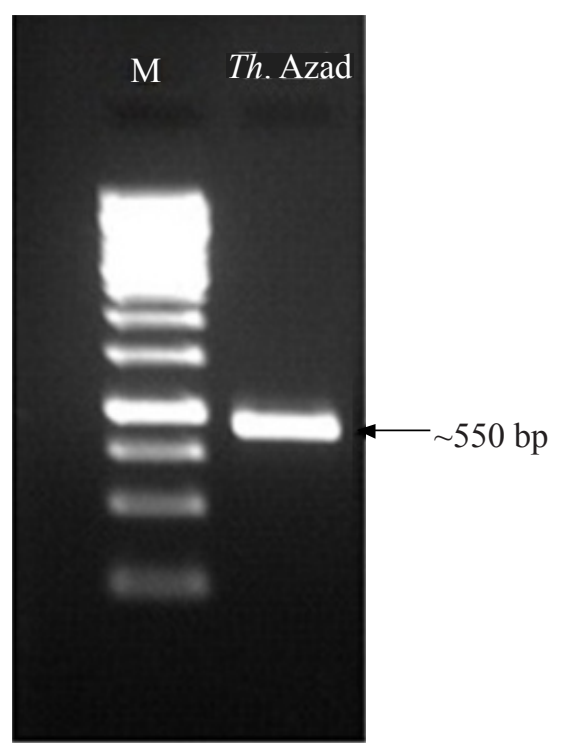

Figure 2: Amplified gene fragment with ITS Marker where, $M$ denotes the marker, Th Azad denote the species T. harzianum (Th Azad)

showed that the gene sequence of isolates has more than $90 \%$ sequence similarity $($ Score $=546$ bits, Expect $=0.0)$ with $18 \mathrm{~S}$ rRNA gene sequence of $T$. hrazianum (Th Azad). (Genbank Acc. Nos.: KC800922).

Bio-control agent T. harzianum (Th Azad) has attained importance for substitute of chemical pesticides and hence an attempt was intended to corroborate the positive relatedness of molecular and morphological characters. The universal ITS primers were used for amplification of the $18 \mathrm{~S}$ gene fragment and strain characterized by using 18S rRNA gene sequence with the help of ITS marker (Shahid et al., 2014).

\subsection{High temperature tolerance}

High temperature tolerance is one of the important physiological adjustments in microbial growth, sporulation and antagonistic activity of the isolate of T. harzianum (Th Azad) against Fusarium oxysporum $\mathrm{f}$. sp. lentis. At $30^{\circ} \mathrm{C}, 1 \times 10^{9} \mathrm{cfu} \mathrm{g}^{-1}$ were observed which declined to $1.2 \times 10^{8} \mathrm{cfu} \mathrm{g}^{-1}$ at $40^{\circ} \mathrm{C}$ and $10^{7}$ cfu g ${ }^{-1}$ at $45^{\circ} \mathrm{C}$ and $50{ }^{\circ} \mathrm{C}$ (Figure 3).

\subsection{Salinity tolerance}

The antagonistic potential of salinity tolerant $T$. harzianum ( $T h$ Azad) isolate against Fusarium oxysporum f. sp. lentis $(\mathrm{Fol})$ was tested, along with their capability to induce relative salt stress tolerance to exploit their use as biological agents in reducing deleterious effects of salinity and controlling Fusarium wilt of lentil under saline soil conditions. Under laboratory conditions, growth decreased significantly with increase in salt concentration in the medium (Daniel et al., 2011). When compared to control plate, $0.1 \mathrm{M}$ salt added medium had $94 \%$ growth followed by $0.5 \mathrm{M}(89.2 \%), 1.0 \mathrm{M}$ (60.\%), 1.5M (34.2\%) growth was observed and at $2 \mathrm{M}$ salt concentration growth was completely inhibited (Figure 4). 


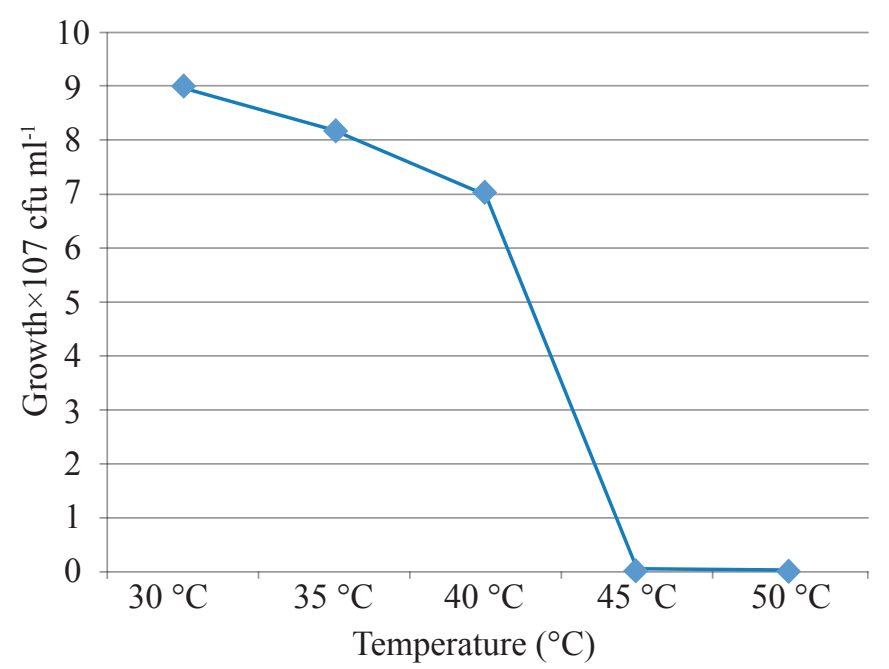

Figure 3: Temperature tolerance of T. harzianum (Th Azad)

Salinity is one of the most widespread constraints to soil fertility (Khan et al., 2001). Preliminary investigations (Kredics et al., 2000) proved that salt stress had significant detrimental effects towards growth, sporulation and antagonistic activity of the wild type isolate of T. harzianum against Fusarium oxysporum.

\subsection{In vitro confrontation assays}

Eco-friendly management of the disease from bio-agents T. harzianum (Th Azad) against Fusarium oxysporum f. sp. lentis was carried out by adopting dual culture technique. The results are interpreted in terms of per cent inhibition over the fungal growth of control and data revealed that $T$. harzianum (Th Azad) suppressed the radial growth of Fusarium oxysporum f. sp. lentis (69.23\%) significantly. Trichoderma species differentially limited the colonical growth of the pathogen, overgrew the pathogen colony and produced yellow pigment. Microscopically, the hyphal interaction indicated that antagonistic hyphae coiled around the hyphae of pathogen,

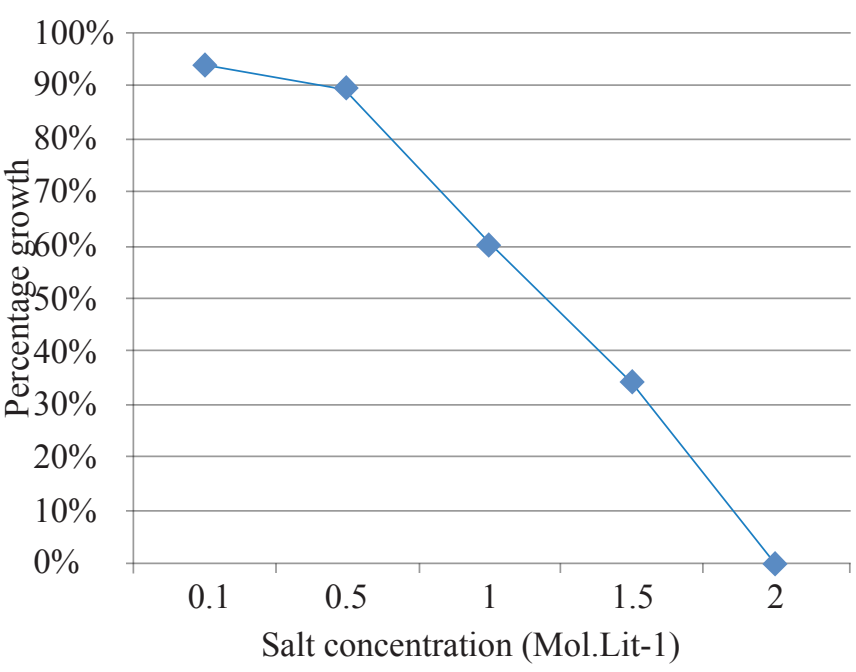

Figure 4: Salinity Tolerance of T. harzianum (Th Azad

denatured the mycelia and finally killed them (Dolatabadi et al., 2012). Trichoderma species either formed hook or bunch like structures around the hyphae of $\mathrm{Fol}$ before penetration, or sometimes entered them directly (Figure $5 \mathrm{a}$ and b, Table 3 ).

In order to survive and compete, Trichoderma produces a wide variety of toxic and antibiotic metabolites that are active against plant pathogens, such as trichodermin, trichodermol, harzianum A, harzianolide, T39 butenolide, terpenes and polypeptides (Lorito et al. 1994; Nakkeeran et al., 2002;

Table 3: In vitro \% inhibition of Fusarium oxysporum f. sp. lentis in presence of bio agent (Th Azad)

\begin{tabular}{lcc}
\hline Treatment & $\begin{array}{c}\text { Radial growth }(\mathrm{mm}) \\
(\text { Fol) }\end{array}$ & \% inhibition \\
\hline Fol+Th Azad & 12.0 & 69.23 \\
Control & 39.0 & 00.00 \\
CD $(p=0.05)$ & & 2.97 \\
\hline
\end{tabular}

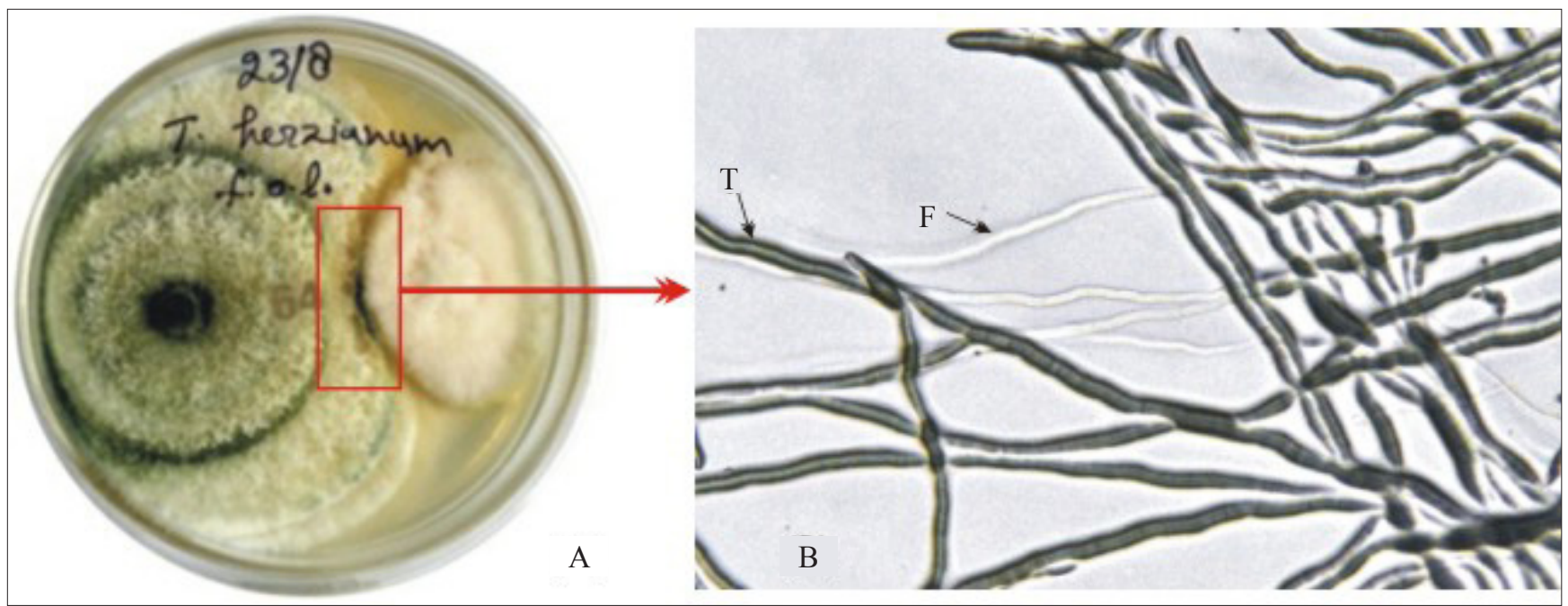

Figure 5: Plate confrontation test of T. harzianum against Fusarium oxysporum f. sp lentis 
Sivasithamparam and Ghisalberti, 1998; Vinale et al., 2008; Andrabi et al., 2011) and extracellular hydrolytic enzymes (Thrane et al., 2000) which were involved in the inhibition, competition, and mycoparasitism of phytopathogenic fungi. In this regard, our results support these findings by showing that $T$. harzianum (Th Azad) produced a good percentage of antibiosis during the antagonistic and competitive growth which restricted establishment, hyphal growth, and sporulation of the pathogen $F$. oxysporum on agar plates.

\subsection{In vitro seed treatment}

Trichoderma spp. is endophytic plant symbionts that are widely used as seed treatments to control diseases and to enhance plant growth and yield. The experimental results of different seed treatments in lentil revealed significant different responses against all the seven seed quality attributes viz. germination, shoot length, root length, seedling length, seedling dry weight, vigour index I and vigour index II (Table 4). $T$. harzianum + vitavax- $\mathrm{T}_{5}$ was found to be significantly superior and effective in increasing $14.67 \%$ more germination of lentil variety KLB 320 from control followed by $\mathrm{T}_{5}(99 \%)$, $\mathrm{T}_{2}(97.66 \%), \mathrm{T}_{1}(96.0 \%), \mathrm{T}_{3}(95 \%)$ and $\mathrm{T}_{16}(84.33 \%)$ (Shukla et al., 2008) similarly the beneficial impact of seed treatment was also recorded for root length, shoot length, seedling length and dry weight vigour index-I and vigour index-II in which $\mathrm{T}_{5}$ treatment (T. harzianum + Vitavax) excelled overall significant superior performance by contributing $1.90 \mathrm{~cm}, 6.99 \mathrm{~cm}, 7.89$ $\mathrm{cm}, 0.85 \mathrm{mg}, 781.11$ and 84.15 , respectively followed by $\mathrm{T} 2$ treatment (Vitavax) for all these physiological attributes by contributing $1.90 \mathrm{~cm}, 5.41 \mathrm{~cm}, 7.31 \mathrm{~cm}, 0.76 \mathrm{mg}, 711.48$ and 73.90 as root length, shoot length, seedling length, dry weight, vigour index-I and vigour index-II respectively.

\subsection{In vivo seed treatment}

The treated seeds were subjected to assess the germination, plant death on different dates, plant survival and yield plant ${ }^{-1}$ during rabi season of 2012-13. The observation on the number of plants dead and the average yield was recorded at 10 days interval starting after the 30 days of the sowing. The experimental results of different seed treatments in lentil revealed significant different responses against all the four seed quality attributes (Table 5 ). $\mathrm{T}_{5}$ treatment ( $T$. harzianum + Vitavax) was found to be significantly superior and effective in increasing $16.6 \%$ more germination from control followed by $\mathrm{T}_{2}(76 \%)$ and $\mathrm{T}_{1}(75 \%)$. Similarly, the impact of seed treatment was also recorded for plant survival where $\mathrm{T}_{2}$ (Vitavax) and $\mathrm{T}_{5}$ (T. harzianum+Vitavax) treatments excelled (both 73.66\%) over all other treatments followed by $\mathrm{T}_{1}$ and $\mathrm{T}_{2}$ Treatments (both $71 \%$ ). Similarly, the average yield was obtained maximum ( $\left.4.16 \mathrm{~g} \mathrm{plant}^{-1}\right)$ in case of $\mathrm{T}_{5}$ treatment $(T$.

\begin{tabular}{|c|c|c|c|c|c|c|c|c|}
\hline $\begin{array}{l}\text { T. } \\
\text { no. }\end{array}$ & Treatment & $\begin{array}{l}\text { Germi-nation } \\
\%\end{array}$ & $\begin{array}{c}\text { Root } \\
\text { length } \\
(\mathrm{cm})\end{array}$ & $\begin{array}{l}\text { Shoot } \\
\text { length } \\
(\mathrm{cm})\end{array}$ & $\begin{array}{c}\text { Seedling } \\
\text { length } \\
(\mathrm{cm})\end{array}$ & $\begin{array}{c}\text { Dry } \\
\text { weight } \\
(\mathrm{mg})\end{array}$ & $\begin{array}{l}\text { Vigour } \\
\text { index I }\end{array}$ & $\begin{array}{l}\text { Vigour } \\
\text { index II }\end{array}$ \\
\hline $\mathrm{T}_{1}$ & T. harzianum (Th Azad) & 96.00 & 1.50 & 5.28 & 6.78 & 0.75 & 650.00 & 72.00 \\
\hline $\mathrm{T}_{2}$ & Vitavax & 97.33 & 1.90 & 5.41 & 7.31 & 0.76 & 711.48 & 73.90 \\
\hline $\mathrm{T}_{3}$ & Chlorpyriphos & 85.00 & 1.00 & 4.48 & 5.48 & 0.64 & 465.8 & 54.40 \\
\hline $\mathrm{T}_{4}$ & Rhizobium & 92.00 & 1.00 & 4.03 & 5.03 & 0.61 & 462.76 & 56.12 \\
\hline $\mathrm{T}_{5}$ & T. harzianum +Vitavax & 99.00 & 1.90 & 6.99 & 7.89 & 0.85 & 781.11 & 84.15 \\
\hline $\mathrm{T}_{6}$ & T. harzianum + Chlorpyriphos & 92.33 & 1.27 & 5.05 & 6.32 & 0.74 & 581.44 & 68.32 \\
\hline $\mathrm{T}_{7}$ & T. harzianum + Rhizobium & 90.66 & 1.50 & 5.12 & 6.62 & 0.65 & 600.16 & 58.92 \\
\hline $\mathrm{T}_{8}$ & Vitavax + Chlorpyriphos & 92.66 & 1.30 & 4.96 & 6.26 & 0.70 & 500.05 & 64.86 \\
\hline $\mathrm{T}_{9}$ & Vitavax + Rhizobium & 88.66 & 1.48 & 4.54 & 6.02 & 0.64 & 533.73 & 56.74 \\
\hline $\mathrm{T}_{10}$ & Chlorpyriphos + Rhizobium & 90.33 & 1.80 & 5.87 & 6.67 & 0.61 & 602.50 & 55.10 \\
\hline $\mathrm{T}_{11}$ & T. harzianum + Vitavax + Chlorpyriphos & 93.33 & 1.83 & 4.86 & 6.69 & 0.64 & 624.37 & 59.73 \\
\hline $\mathrm{T}_{12}$ & T. harzianum + Vitavax + Rhizobium & 93.00 & 1.88 & 5.08 & 6.96 & 0.65 & 647.28 & 60.45 \\
\hline $\mathrm{T}_{13}$ & T. harzianum + Chlorpyriphos + Rhizobium & 88.00 & 1.40 & 5.17 & 6.57 & 0.63 & 578.16 & 55.44 \\
\hline $\mathrm{T}_{14}$ & Vitavax + Chlorpyriphos + Rhizobium & 87.33 & 1.79 & 4.10 & 6.89 & 0.63 & 601.70 & 55.01 \\
\hline $\mathrm{T}_{15}$ & $\begin{array}{l}\text { T.harzianum }+ \text { Chlorpyriphos }+ \text { Vitavax }+ \\
\text { rhizobium }\end{array}$ & 86.66 & 1.52 & 4.50 & 6.02 & 0.70 & 521.69 & 60.66 \\
\hline \multirow[t]{2}{*}{$\mathrm{T}_{16}$} & Control & 84.33 & 1.00 & 3.83 & 5.83 & 0.60 & 491.64 & 50.59 \\
\hline & $\mathrm{CD}(p=0.05)$ & 6.14 & 1.07 & 1.47 & 1.79 & 0.35 & 148.47 & 1.19 \\
\hline
\end{tabular}




\begin{tabular}{|c|c|c|c|c|c|c|c|c|}
\hline \multirow[t]{2}{*}{ Treatment } & \multirow[b]{2}{*}{$\begin{array}{c}\% \\
\text { germination* }\end{array}$} & \multicolumn{5}{|c|}{$\begin{array}{l}\text { No. of plants dead on different } \\
\text { dates }\end{array}$} & \multirow[t]{2}{*}{$\begin{array}{l}\% \text { plant } \\
\text { survival }\end{array}$} & \multirow{2}{*}{$\begin{array}{l}\text { Average } \\
\text { yield plant } \\
\text { (in g) }\end{array}$} \\
\hline & & $\begin{array}{l}\cong \\
\beth \\
\beth \\
\Xi\end{array}$ & $\begin{array}{l}\underset{c}{d} \\
\underset{d}{d}\end{array}$ & $\begin{array}{l}m \\
\stackrel{m}{0} \\
\dot{0}\end{array}$ & $\begin{array}{l}m \\
\stackrel{m}{0} \\
\stackrel{0}{\Xi}\end{array}$ & $\begin{array}{l}m \\
\stackrel{m}{\dot{a}} \\
\stackrel{i}{\sim}\end{array}$ & & \\
\hline $\mathrm{T}_{1}-T$. harzianum (Th Azad) & 79.33 & 1.33 & 1.67 & 1.33 & 0.67 & 0.67 & 73.67 & 4.16 \\
\hline $\mathrm{T}_{2}$-Vitavax & 76.33 & 0.67 & 0.67 & 0.67 & 0.33 & 0.33 & 73.67 & 3.67 \\
\hline $\mathrm{T}_{3}$-Chlorpyriphos & 68.67 & 1.33 & 2.00 & 1.33 & 0.67 & 0.67 & 62.67 & 2.74 \\
\hline $\mathrm{T}_{4}$-Rhizobium & 71.00 & 1.33 & 1.67 & 0.67 & 0.33 & 0.33 & 66.67 & 3.24 \\
\hline $\mathrm{T}_{5}-T$. harzianum +Vitavax & 75.00 & 1.67 & 0.67 & 1.00 & 0.00 & 0.00 & 71.67 & 3.73 \\
\hline $\mathrm{T}_{6}-T$. harzianum + Chlorpyriphos & 67.33 & 1.00 & 1.00 & 1.00 & 1.00 & 1.00 & 67.33 & 3.06 \\
\hline $\mathrm{T}_{7}-T$. harzianum + Rhizobium & 69.00 & 2.00 & 0.67 & 1.00 & 0.00 & 0.00 & 65.33 & 3.24 \\
\hline $\mathrm{T}_{8}$-Vitavax + Chlorpyriphos & 72.67 & 1.33 & 1.00 & 0.67 & 1.00 & 1.00 & 68.00 & 3.05 \\
\hline $\mathrm{T}_{9}$-Vitavax + Rhizobium & 72.67 & 1.00 & 0.67 & 0.33 & 0.00 & 0.00 & 70.67 & 3.07 \\
\hline $\mathrm{T}_{10}-$ Chlorpyriphos + Rhizobium & 69.33 & 1.00 & 1.33 & 1.33 & 1.00 & 1.00 & 63.67 & 3.01 \\
\hline $\mathrm{T}_{11}-$ T. harzianum + Vitavax + Chlorpyriphos & 74.00 & 1.67 & 1.33 & 1.00 & 1.33 & 1.33 & 67.33 & 3.32 \\
\hline $\mathrm{T}_{12}-T$. harzianum + Vitavax + Rhizobium & 75.00 & 1.00 & 0.00 & 1.00 & 1.00 & 1.00 & 71.00 & 3.70 \\
\hline $\mathrm{T}_{13}-$ T.harzianum + Chlorpyriphos + Rhizobium & 71.00 & 1.00 & 1.33 & 0.67 & 0.33 & 0.33 & 67.33 & 3.50 \\
\hline $\mathrm{T}_{14}-$ Vitavax + Chlorpyriphos + Rhizobium & 73.00 & 2.00 & 2.00 & 0.00 & 0.33 & 0.33 & 68.33 & 3.54 \\
\hline $\begin{array}{l}\mathrm{T}_{15}-T . \text { harzianum }+ \text { Chlorpyriphos }+ \text { Vitavax }+ \\
\text { Rhizobium }\end{array}$ & 71.00 & 0.67 & 2.33 & 2.00 & 0.00 & 0.00 & 67.67 & 3.67 \\
\hline $\mathrm{T}_{16}-$ Control & 68.00 & 3.67 & 2.00 & 2.67 & 2.00 & 2.00 & 48.67 & 2.30 \\
\hline $\mathrm{SE}(\mathrm{d})$ & 1.769 & & & & & & 1.837 & 0.722 \\
\hline $\mathrm{CD}(p=0.05)$ & 5.281 & & & & & & 7.420 & 0.599 \\
\hline
\end{tabular}

harzianum + Vitavax). Percent plant survival and yield plant ${ }^{1}$ are important attributes, which determine the quality of seed. Mastouri et al. (2010) also concluded that seed treatment with Trichoderma harzianum stain $\mathrm{T}_{22}$ increases seedling vigor and ameliorates stress by inducing physiological protection in plants against oxidative damage. To find a new bio-control agent that is efficient to control plant diseases, it is important to screen a number of possible candidates by evaluating several preliminary characteristics. The reason behind evaluation of abiotic stress tolerance in the current strain was that the stress tolerant strains can be efficiently deployed in extreme environments where they can show better rhizosphere competence and saprophytic competitive ability. Interestingly, some of the abiotic stress tolerant microbes also protected plants from abiotic stresses like drought (Timmusk and Wagner, 1999), chilling injury, high temperature, and salinity. Several successful trials had been made to increase the biocontrol potential of Trichoderma species under a wide range of adverse environmental conditions by exposing the spores to chemical e.g., EMS or physical mutagens, e.g., gamma rays. Mutation has been suggested to improve growth characters, antifungal metabolites production and antagonistic potential of $T$. harzianum against $F$. oxysporum under saline conditions (Abdel et al., 2006).

\section{Conclusion}

Th Azad isolate has the ability to withstand different abiotic stresses suggesting that the inoculant has better survival, efficacy, adaptability and plant productivity with all the seven seed quality attributes viz. germination, shoot length, root length, seedling length, seedling dry weight, vigour index I and vigour index II. This study has identified a potential strain of abiotic stress tolerant T. harzianum (Th Azad) capable of effectively controlling wilt disease. Results of field trial experiments are in conformity to that of the lab experiment where, treatments $\mathrm{T}_{5}$ (T. harzianum+vitavax) was found the best seed treatment in enhancing the quality of the seed and productivity.

\section{Acknowledgement}

The authors are grateful to the financial support granted by the ICAR under the Niche Area of Excellence on "Exploration 
and Exploitation of Trichoderma as an antagonist against soil borne pathogens" running in Department of Plant Pathology, CSAUA\&T, Kanpur-208002, U. P., India.

\section{References}

Abdel- Latif, H.A., Wafaa, M., Haggag, M., 2006. Biocontrol potential of salinity tolerant mutants of Trichoderma harzianum against Fusarium oxysporum. Brazilian Journal of Microbiology 37, 181-191.

Abdul Baki, A.A., Anderson, J.D., 1973. Vigour determination in soybean seed by multiple criteria. Crop Science 13, 630-633.

Andrabi, M., Vaid, A., Razdan, V.K., 2011. Evaluation of different measures to control wilt causing pathogens in chickpea. Journal of Plant Protection Research 51 (1), 55-59.

Bauske, E.M., Kirby, H.W., 1992. Effects of dinitroaniline herbicides and rhizoctonia disease of soybeans. Plant Disease 76, 236-239.

Bisset, J., 1991a. Arevision of the genus Trichoderma II. Infragenric classification. Canadian Journal of Botany 69, 2373-2417.

Bisset, J., 1991b. A revision of the genus Trichoderma III. Sect. Pachybasium. Canadian Journal of Botany 69, 2373-2417.

Booth, C., 1971. The Genus Fusarium. Kew, England: Commonwealth Mycological Institute.

Cole, J.R., Wang, Q., Cardenas, E., Fish, J., Chai, B., 2009. The Ribosomal Database Project: improved alignments and new tools for rRNA analysis. Nucleic Acids Research 37, 141-145.

Crowhurst, R.N., King, F.Y., Hawthorne, B.T., Sanderson, F.R., Choi-Pheng, Y., 1995. RAPD characterization of Fusarium oxysporum associated with wilt of angsana (Pterocarpus indicus) in Singapore. Mycological Research 99, 14-18.

Daniel, L., Amalraj, E., Kumar, P.G., Desai, S., Mir Hassan Ahmed, S.K., 2011. In vitro Characterization of Trichoderma viride for Abiotic Stress Tolerance and Field Evaluation against Root Rot Disease in Vigna mungo L. Journal of Biofertilizers \& Biopesticides 2, 2155-6202.

Dolatabadi, H., Mohammadi, K., Mohammadi, G., Rabiey, E., Rohani, N.M., Varma, A., 2012. Biocontrol Potential of Root Endophytic Fungi and Trichoderma Species Agains Fusarium Wilt of Lentil Under In vitro and Greenhouse Conditions, Journal of Agricultural Science Technology 14, 407-420.

Halford, N.G., 2009. New insights on the effects of heat stress on crops. Journal of Experimental Botany 60, 4215-4216.
Harman, G.E., Bjorkman, T., 1998. Potential and existing uses of Trichoderma and Gliocladium for plant disease control and plant growth enhancement. Trichoderma and Gliocladium. Taylor and Francis, London United Kingdom.

Harman, G.E., Howell, C.R., Viterbo, A., Chet, I., Lorito, M., 2004. Trichoderma species-opportunistic, avirulent plant symbionts. Nature Review Microbiology 2, 43-56.

Harman, G.E., Jin X., Stasz, T.E., Peruzzotti, G, Leopold, A.C., 1994. Method of increasing the percentage of viable dried spores of a fungus. US Patent Number, 5288, 634.

Hiney, M., Dawson, M.T., Heery, D.M., Smith, P.R., Gannon, F., Powell, R., 1992. DNA probe for Aeromonas salmonicida. Applied and Environmental Microbiology 58, 1039-1042.

Johnson, L.F., Curl, E.A., 1972. Methods for Research on the Ecology of soil borne Plant Pathogens. Burgess Publishing Company. Minneapolis, 247.

Khan, M.A., Gul, B., Weber, D.J., 2001. Effect of salinity on the growth and ion content of Salicornia rubra. Communications in Soil. Communications in Soil Science and Plant Analysis 32, 2965-2977.

Kleifeld, O., Chet, I., 1992. Trichoderma harzianum-interaction with plants and effect on growth response. Plant Soil 144, 267-272.

Kredics, L., Antal, Z., Manczinger, L., 2000. Influence of water potential on growth, enzyme secretion and in vitroenzyme activities of Trichoderma harzianum at different temperatures. Current Microbiology 40, 310-314.

Kubicek, C.P., Mach, R.L., Peterbauer, C.K., Lorito, M., 2001. Trichoderma: From genes to biocontrol. Journal of Plant Pathology 83, 11-23.

Lorito, M., Peterbauer, C., Hayes, C.K., Harman, G.E., 1994. Synergistic interaction between fungal cell wall degrading enzymes and different antifungal compounds enhances inhibition of spore germination. Microbiology 140 (3), 623-629.

Leslie, J. F., Summerell, B. A., 2006. The Fusarium laboratory manual. Ames, IA: Blackwell Publishing Professional.

Mastouri, F., Bjorkman, T., Harman, G.E., 2010. Seed treatment with Trichoderma harzianum alleviates biotic, abiotic, and physiological stresses in germinating seeds and seedlings. Phytopathology 100, 1213-1221.

Morton, D.T., Stroube, N.H., 1955. Antagonistic and stimulatory effects of microorganism upon Sclerotium rolfsii. Phytopathology 45, 419-420.

Nakkeeran, S., Krishnamoorthy, A.S., Ramamoorthy, V., Renukadevi, 2002. Microbial inoculants in plant disease control. Journal of Ecobiololy 14, 83-94.

Nene, Y.L., Thapaliyal, P.N., 1977. Fungicides in plant disease 
control. Oxford and IBH Delhi, 507.

Papavizas, G.C., 1985. Trichoderma and Gliocladium: Biology, ecology and potential for biocontrol. Annual Review of Phytopathology 23, 23-54.

Punja, Z.K., 1988. Sclerotium (Athelia) rolfsii, a pathogen of many plant species. Advances in Plant Pathology, Academic Press San Diego CA USA.

Shahid, M., Srivastava, M., Singh, A., Kumar, V., Rastogi, S., Pathak, N., Srivastava, A.K., 2014. Comparative Study of Biological Agents, Trichoderma harzianum (Th Azad) and Trichoderma viride (01PP) for Controlling Wilt Disease in Pigeon Pea. J Microbial \& Biochemical Technology 6, 110-115.

Shailbala, Tripathi, H.S., 2004. Seed treatment with fungicides and biocontrol agent on pathogens in urdbean seeds. Journal of Mycology and Plant Pathology 34, 851-852.

Shukla, G., Suman, M., Chakravarty, S., 2008. Presowing Treatments on Germination and Seedling Growth of Terminalia arjuna in Terai Zone of West Bengal. Seed Research 36, 183-186.

Singh, A., Shahid, M., Sachan, C.P., Srivastava, M., Biswas, S.K., 2013. Effect of seed treatment on germination and vigour Lentil. Journal of Plant Disease Science 8, 124-125.

Singh, A., Shahid, M., Srivastava, M., 2014. Phylogenetic relationship of Trichoderma asperellum Tasp/8940 using Internal Transcribed Spacer (ITS) sequences. International Journal of Advance Research 2(3), 979-986.

Sivasithamparam, K., Ghisalberti, E.L., 1998. Secondary metabolism in Trichoderma and Gliocladium. p. 139-191. In: "Trichoderma and Gliocladium, Volume I" (C.P. Kubicek, G.E. Harman, eds.). Taylor and Francis Ltd.
London, UK, 300.

Tanwar, A., Aggarwal, A., Panwar, V., 2013. Arbuscular mycorrizal fungi and Trichoderma viride mediated fusarium wilt control in tomato. Biocontrol Science and Technology 23(5), 485-498.

Tamura, K., Dudley, J., Nei, M., Kumar, S., 2007. MEGA4: Molecular Evolutionary Genetics Analysis (MEGA) software version 4.0. Molecular Biology Evolution 24, 1596-1599.

Thompson, J.D., Higgins, D.G., Gibson, T.J., 1994. CLUSTAL $\mathrm{W}$ : improving the sensitivity of progressive multiple sequence alignment through sequence weighting, position-specific gap penalties and weight matrix choice. Nucleic Acids Research 22, 4673-4680.

Thrane, C., Jensen, D.F., Tronsmo, A., 2000. Substrate colonization, strain competition, enzyme production in vitro, and biocontrol of Pythium ultimum by Trichoderma spp. isolates $\mathrm{P}_{1}$ and $\mathrm{T}_{3}$. European Journal of Plant Pathology 106 (3), 215-225.

Timmusk, S., Wagner, E.G.H., 1999. The plant growthpromoting rhizobacterium Paenibacillus polymyxa induces changes in Arabidopsis thaliana gene expression: a possible connection between biotic and abiotic stress responses. Molecular Plant Microbe Interaction 12, 951-959.

Verma, V., Kasera, P.K., 2008. Standardization of seed germination aspects in asparagus racemosus Willd. and Sida Cordifolia Linn. in arid region of India. Seed Research 36, 176-182.

Vinale, F., Sivasithamparam, K., Ghisalberti, E.L., Marra, R., Woo, S.L., Lorito, M., 2008. Trichoderma-plantpathogen interactions. Soil Biology and Biochemistry 40 (1), 1-10. 